\title{
Revolta e proclamação como molduras da história: escrita da história e olhares para a República entre os sócios do IHGB
}

\author{
Revolts and proclamation as historical frames: writing of history and \\ visions of the Republic by the members of the IHGB
}

\author{
Francisco Gouvea de Sousa \\ chico_gouvea@yahoo.com.br \\ Pesquisador \\ Programa Nacional de Pós-Doutorado \\ Universidade de Ouro Preto \\ Rua do Seminário, s/n - Centro \\ 35420-000 - Mariana - MG \\ Brasil
}

\section{Resumo}

Os olhares e vozes dos sócios do Instituto Histórico e Geográfico Brasileiro (IHGB) em relação à República de 1889 foram intensamente marcados por formas de ver o passado antes mobilizadas pela escrita da história. Enquanto alguns sócios experimentavam o retorno da anarquia regencial, outros se referiam ao 15 de novembro pela mesma moldura que deu forma à Independência, falando de uma proclamação. Para expor o quanto estas formas de compreensão do passado foram ativas na compreensão da vida política, este artigo percorre, num segundo momento, algumas memórias históricas escritas pelos mesmos sócios que experimentaram o 15 de novembro ainda no Segundo Reinado; para, ao final, demonstrar que a reaproximação entre Instituto Histórico e vida do governo não marcou apenas um envolvimento de letrados e conselheiros do Império com a República, mas também a permanência de um repertório de formas de ver o passado e, por ele, o presente.

\section{Palavras-chave}

Instituto Histórico e Geográfico Brasileiro (IHGB); República; Historiografia.

\begin{abstract}
The views and voices of the members of the Instituto Histórico e Geográfico Brasileiro (IHGB) in relation to the Republic of 1889 were intensely marked by a repertoire that had already been mobilized by the writing of history. While some members experienced the return of the anarchy particular to the Regency period, others conceived the $15^{\text {th }}$ of November by the same frame that had been used to comprehend the Independence, and referred to it as a proclamation. To address how these ways of understanding the past were active in the comprehension of politics, this article examines some historical memoirs written by the same literates who still experienced the $15^{\text {th }}$ of November in the Second Reign. The article concludes that the involvement of the Historical Institute with the government was more than only a connection between scholars and counselors of the Empire with the Republic: it was also the permanence of a repertoire of ways of seeing the past and, through the past, also of ways of seeing the present.
\end{abstract}

Keywords

Instituto Histórico e Geográfico Brasileiro (IHGB); Republic; Historiography.

Recebido em: 8/9/2014

Aprovado em: 12/4/2015 
Senhores! Imperioso dever do meu cargo me força a anunciar-vos que jamais nessa cadeira se assentará aquele que durante quarenta anos desempenhou verdadeiramente o título de protetor de nossa associação [...]. Das atas das sessões de nossos trabalhos e das nossas sessões magnas, celebradas na sua casa com todo esplendor e solenidade, consta, e constará sempre, o que foi o Imperador D. Pedro II para com o Instituto Histórico, que Ihe retribui numerosos favores com a maior gratidão, por considerá-lo como seu primeiro aluno e por tê-lo sempre como seu desvelado protetor (SILVA 1889, p. 534).

As palavras de Joaquim Norberto, em sessão regular do Instituto Histórico e Geográfico Brasileiro (IHGB), do qual era presidente em 1889, marcaram como a República foi vivida por uma parte dos letrados da cidade do Rio de Janeiro ao fim do oitocentos. Para eles, a República foi uma ausência, como a cadeira de D. Pedro II que permaneceria vazia até mesmo quando, alguns anos depois, o IHGB retomaria o contato com a vida do governo. Na sessão aniversária de 1894, conduzida pelo então presidente do IHGB e do Supremo Tribunal Federal Olegário Herculano de Aquino e Castro, Prudente de Morais compareceu ao Instituto Histórico; porém, não se senta na cadeira do "Imediato Protetor do Instituto Histórico".

O respeito pela imagem de $D$. Pedro II indica que na reaproximação do IHGB com a vida do governo ao longo dos governos civis republicanos, o Império era respeitado como um passado nacional. Por ele, letrados e conselheiros se aproximavam da República. Ao mesmo tempo, assumindo o Império como 214 herança, conceitos e formas de compreensão da vida política, como as molduras proclamação e revolta, permaneceriam ativas. Antes desta reaproximação, porém, entre os anos de 1889 a 1894, a vida dos sócios do instituto foi intensa.

Não sem motivos. Ao longo de todo o Segundo Reinado, o IHGB viveu "sob a imediata proteção de sua Majestade Imperial" (GUIMARÃES 1995). Nesta relação próxima com D. Pedro II, os letrados tiveram como direção responder questões como qual o lugar do Brasil entre as nações civilizadas e que passado teria essa nação, produzindo uma "retórica da nacionalidade" (CEZAR 2006). Este dever teve longa duração no Instituto. Não é de se estranhar que os sócios lamentassem a perda de seu "primeiro aluno" e "desvelado protetor". O que produzia mais ansiedade, porém, era o que se dava fora do IHGB nesses anos. Para além da ausência, o que os constrangia era o desencontro, a conspiração, o ruído.

Não foi este, entretanto, o único olhar para a República de 1889 entre os sócios do Instituto. Para outros, o 15 de novembro era o inverso da conspiração, e portanto aparecia como um acontecimento previsto e irresistível: era uma proclamação. ${ }^{1}$ A revista do Instituto de 1890 já trazia, em uma biografia (SILVEIRA 1890), a imagem de um passado para a proclamação através de seus "dignos precursores", no caso Libero Badaró e Tiradentes, personagem

\footnotetext{
${ }^{1}$ Embora estes sócios do IHGB não o explicitem, o argumento da inevitabilidade da República estava presente desde os anos 1880, nas vozes de personagens como Silva Jardim. O centenário da Revolução Francesa agia como uma referência poderosa para reforçar o lugar daquele ano na campanha republicana. Como se sabe, porém, estes republicanos mais afeitos à palavra da rua, ao discurso para muitos, não tiveram mais espaço na República do que tinham ao fim do Império.
} 
que passava por ampla disputa até mesmo antes da República (SIMAS 1994). Se Joaquim Norberto não estava sozinho em seu constrangimento frente à República, Argemiro Silveira foi um dos sócios que reconheceu prontamente que a República teve "precursores".

Os sócios do Instituto, assim, não experimentaram a República de 1889 de forma homogênea, tiveram compreensões contrastantes sobre o 15 de novembro, mobilizando palavras e climas distintos. Se este artigo lida com tais perspectivas divergentes investigando, para isso, uma parte menos frequentada da produção dos sócios do $\mathrm{IHGB}^{2}{ }^{2}$ o interesse deste texto não se limita à compreensão e exposição destes. Pois, entre os olhares para a República e as escritas da história dos sócios do Instituto, é possível levantar uma indagação quanto às relações entre historiografia e vida política, sobre suas interseções e trocas.

Se Proclamação e revolta foram molduras que interferiram na compreensão da República, simultaneamente, orientaram formas de ver a vida política. Assim como uma moldura destaca a pintura de tudo o que a cerca, concentrando o olhar apenas em seu interior, um evento é como uma cena, ele depende de algo que lhe é exterior e pelo qual se destaca do passado assumindo uma identidade. Proclamação e revolta, enquanto molduras, não definem a ação que se desenrola na cena, mas suas margens e limites. Ao mesmo tempo, são heranças que permanecem na linguagem.

O argumento central deste texto, assim, é que os olhares para a República entre os sócios do IHGB foram orientados por referências que já haviam sido mobilizadas pela escrita da história. Por isso, as escritas da história anteriores à República também são objeto para este artigo.

Nessa direção, existe uma correspondência entre o olhar e a voz. A tessitura de uma voz é, nesse caso, próxima à capacidade de olhar. Tessitura é um conceito adequado na medida em que fala da extensão de uma voz, sua capacidade de variar em altura (do grave ao agudo). Do olhar à voz que comentava a República de 1889 , formas a princípio próprias à escrita da história davam sentido ao presente.

É já um dado importante que estas formas, revolta ou proclamação, ocupavam lugares distintos. Para aqueles que viam o 15 de novembro como desencontro, a República era assunto nas sessões regulares. Os que viveram uma proclamação, porém, escreviam história. No primeiro caso, as falas das sessões eram repletas de passado, mas não ocorriam, enquanto discurso, como história, salvo algumas exceções. Deve-se adiantar também que não eram apenas os monarquistas que recuperariam o passado recente ao Império para dar forma aos acontecimentos da República de 1889. Ao falar sobre Canudos, um sócio favorável à República como Aristides Milton dizia:

\footnotetext{
2 Se Lucia Guimarães e Ângela de Castro Gomes lidaram com a produção do IHGB na República, suas reflexões falam mais de uma segunda geração pós-proclamação e de um momento em que o Instituto já tinha retomado suas relações com a vida do Governo. Ainda assim, são referências importante para este artigo. A Dissertação de Hugo Hruby é uma referência que lida mais diretamente com o tempo sobre o qual este artigo discorre, assim como alguns artigos seus. De sua Dissertação, destaco especialmente a leitura atenta dos pareceres às obras submetidas à avaliação após a República. A partir deles, o autor trabalha as tensões não só internas à historiografia, mas também na relação entre escrita da história e contexto político.
} 
A mesma tendência revolucionária que, desde 1822 até 1848 , trouxeram pendente da sorte das armas o futuro do Império e, predominando ora aqui, ora acolá, celebrizara esse quarto de século por uma agitação constante e lutas fratricidas de pungitiva lembrança, havia ressurgido na plenitude de sua funesta energia para perturbar o regime, que em 1889, tinha sido inaugurado (MILTON 1900, p. 5).

O argumento específico desse texto é que não se deveria culpar a República pela desordem. Dizia Milton que nenhuma forma de governo era responsável pela psicologia social do povo. A causa de Canudos não era a República - como queriam os monarquistas contra quem Milton se contrapunha - mas o povo, liderado por um insano extraordinário. Mais do que esta intenção e contexto particular ao discurso de Milton, para este artigo a citação interessa como forma de mostrar como pelo olhar para o passado se estruturam molduras pelas quais se compreende e se age no presente. Essas formas de compreensão herdadas não nascem de reflexões conceituais propriamente. Aristides Milton não compara Canudos a um conceito específico de desordem, mas à impressão que as regências geram como um todo.

O olhar para o 15 de novembro que via uma proclamação, porém, traduzia-se em escrita da história. O presente, como proclamação, era compreendido enquanto narrativa. Estes letrados faziam parte de um cenário mais amplo, no qual "republicanos desejavam integrar o Brasil ao mundo americano, identificado com o regime republicano e com a modernidade" (LIPPI 1990, p. 23). O passado

216 colonial se tornava um passado negativo a ser superado, ao mesmo tempo em que os levantes que se deram nele se tornavam referências fundamentais para expor uma disposição inata para a República na América. A América se tornava, como em "O movimento colonial na América", de Tristão de Alencar Araripe, espaço de um processo irresistível. Aliás, Tristão de Alencar Araripe não só narrou um passado para a República de 1889, como integrou a vida dos primeiros governos.

As vozes e olhares para a República ganhavam forma, assim, entre comentários sobre o presente em desencontro e em escritas da história que narravam uma proclamação. De um lado ao outro, as formas de ver o passado compunham possibilidades de compreensão da vida política.

\section{A República como anarquia}

As recepções da República entre os sócios do IHGB não compõem uma parte decisiva na vida da República como foram os debates vividos desde 1880 (MELLO 2007). Porém, nelas estão expressas formas que deram direção à vida política. De um lado, a República como desencontro (entropia diria um historiador recente) ${ }^{3}$ do outro, como inevitável.

\footnotetext{
${ }^{3}$ A invenção republicana pode ser dividida em dois momentos. Num primeiro, Renato Lessa se dedica a comentar o que chama de entropia, a compreensão de que o início da República foi marcado pela dispersão de forças políticas sem resultado construtivo. Parte dessa impressão se forma por um argumento também caro a José Murilo de Carvalho em A formação das almas, de que os primeiros governos sofreram de uma ausência efetiva de projeto. Esta ausência, por sua vez, é confirmada pela não aversão ou crítica direta do Império. A presença de continuidades, ou falta de rupturas, permite falar de fragilidades da República. Porém,
} 
Um dos olhares para o 15 de novembro se deu por uma moldura recorrente quando se fala de história oitocentista, a moldura da revolta. Se em 1889 algo novo acontecia, a forma era conhecida.

Senhores. - Achamo-nos em um campo neutro, onde não entra a política com as suas tergiversações e sutilezas. Lá fora esbraveja de noite e de dia o ruído dos interesses desencontrados e antagonistas; [...] o patriotismo, que é santo e nobre, encarado por prismas diversos. Aqui o silêncio de que medito; a paz e a serenidade de ânimo do que se afadiga por honrar o renome nacional, zelando o renome de seus filhos ilustres e arquivando os fatos memoráveis da história pátria (MELLO 1890, p. 561).

O relatório do secretário do IHGB não cumpria exatamente sua função de comentar a produção do ano que terminava, falava da vida do Instituto e, principalmente, do presente. Ele indica a tessitura da voz de parte dos sócios quando a República se dá, o ruído de lá contra o silêncio de que medito. Não implica uma ausência de divergências, mas um controle sobre como e onde elas se dão. "As controvérsias dos sábios, se às vezes se azedam, tal a humana fragilidade! não excitam prevenções, suspeitas, perseguições. Os sábios, como tais, não conspiram" (CORREIA 1897, p. 417). Esta mesma imagem do sócio Manuel Correa, "os sábios não conspiram", já tinha aparecido algumas vezes desde o 15 de novembro. No parecer sobre a obra que narra o momento do exílio e pela qual Afonso Celso ingressaria no Instituto, era o próprio D. Pedro II quem falava:

E igualmente admirável mostra-se em muitas ocasiões, como quando, por exemplo, dilacerado o coração por ver-se expatriado, banido, declara que voltaria ao Brasil, contentíssimo e no mesmo instante em que o chamassem para prestar-Ihe serviços; por uma conspiração, porém, nunca. "Conspirar - diz ele então - jamais. Não se coaduna com a minha índole, o meu caráter, os meus precedentes; seria a negação da minha vida inteira" (BLAKE 1892, p. 375).

Assim começa a aparecer o que interessa. A inquietação com o "ruído dos interesses desencontrados" não era uma postura vaga, mas decidida. Falavam pela defesa de uma relação unívoca com a nação, negavam os partidos, negavam "os prismas variados". Para eles, o que ocorria "fora" do Instituto era a conspiração. Um argumento próprio da escrita da história mostrava sua natureza. A compreensão de que é necessário distanciamento do objeto dependia de não expor claramente qual a intenção e intencionalidade em se falar dele.

a ruptura na forma de governo não implicava, para os homens que a viveram, a necessidade de um conteúdo radicalmente distinto. Em seu discurso de 1890, na comemoração de um ano da Proclamação, Deodoro da Fonseca deixava claro que o passado não era monarquia, mas nação, especialmente no que tange às leis. Assim, a continuidade se dava pela compreensão de que a dicotomia Monarquia contra República não deve envolver o que é do âmbito do nacional. Nesse sentido, este artigo caminha em direção diferente daquela que inicia $A$ invenção republicana, pois que reconhece que a permanência de formas e conteúdos próprios do Império era uma escolha ativa do projeto republicano em construção, na medida em que estes apareciam enquanto construtores e herdeiros. A segunda parte do livro, porém, dedicado mais diretamente ao governo e à vida política de Campos Sales nos parece uma referência que ainda deve ser mantida, especialmente por destacar que o conceito de administração dos governos civis era uma herança do Império. Não sem razão, Lessa apresenta Campos Sales como leitor de Visconde do Uruguai. 
Intenção é o que se pretende com o gesto. No caso da fala de Teixeira de Mello, a intenção era separar nação da forma do governo. Era dizer que o passado recente de 1889 não era a monarquia, mas um passado nacional. A intencionalidade compreende o horizonte da ação, a tessitura da voz, o que se considera possível de ser dito. Nela não opera o que Gumbrecht chama de "motivo-para-que" (descrito aqui como intenção), mas um "motivo-por-que". O que os sócios do Instituto tinham como possível de ser dito, nessa direção, tem relação direta com o passado que compõe a situação da fala. "[...] o nosso conceito de situação, inicialmente direcionado apenas para a situação comunicativa, é ampliado pelo seu passado" (GUMBRECHT 2003, p. 30). Por isso, não basta ouvir as vozes dos sócios enquanto circunscritas exclusivamente em uma sincronia, mas sim de vê-las pelo passado que lhes dá forma e sentido.

O "patriotismo encarado por prismas diversos" seria uma tópica reproduzida em diferentes momentos nas sessões de 1889 a 1894, e não só nelas. A voz na rua, a "imprensa que inflama", a "revolta no sertão" - como a comparação direta de Canudos com as revoltas regenciais -, a "degola" no sul, os canhões da armada que interrompiam, em 1893, o funcionamento do Instituto para esses letrados, e não só para eles, os primeiros anos da República foram como uma reaparição dos ruídos próprios dos anos regências. Nos anos de 1870, parte destes sócios que experimentaram o 15 de novembro representaram ruídos de mesmo timbre em suas escritas da história e falas em sessões regulares. Era

218 essa forma de representação que retornava.

Essa moldura - a revolta - não estava explícita nem em 1890, nem quando era mobilizada em 1870, muito menos ganhou vida por uma História Geral, mas por uma espécie de coleção de memórias históricas que se deu ao longo das publicações de 1870 a 1890. As regências, já adianto, estavam num passado indisponível à compreensão sistemática, algo distinto da Independência.

\section{A revolta como moldura}

Talvez as memórias históricas sobre as regências sejam uma parte pouco estudada da produção do Instituto por serem, em sua maior parte, narrativas pontuais. É difícil atribuir a qualquer uma delas um destaque ou centralidade. O lugar que parecem ocupar é o de uma coleção e, como tal, são organizadas por alguns princípios: pelo clima das regências e pela revolta como moldura. Manuel Duarte Moreira de Azevedo foi dos sócios que mais escreveu memórias históricas sobre as regências. ${ }^{4}$ Através da sua escrita vamos sintetizar traços principais de como, desde os anos de 1870, as regências apareciam.

No início, existe um tempo específico:

\footnotetext{
${ }^{4}$ Enquanto autores de memórias históricas de 1870 a 1889, Lúcia Guimarães destaca que: "Das 92 monografias impressas no período de 1838-1889, 37 foram escritas por ele. O que em termos percentuais corresponde a aproximadamente $40 \%$ daquele total. Fernandes Pinheiro Contribuiu com 15 textos, Moreira de Azevedo com 17, e Alencar Araripe com cinco, durante o período estudado" (GUIMARÃES 1995, p. 586). Entre os anos 1870 a 1890, o passado recente ao Segundo Reinado foi comentado por: Manuel Moreira de Azevedo, com onze artigos; Tristão de Alencar Araripe, com quatro artigos; Alves Sacramento Blake com dois artigos; cônego Fernandes Pinheiro e Pereira de Alencastre, com um artigo cada.
} 
Em 7 de abril [de 1831] a nação quebrou os últimos anéis da corrente que parecia trazê-la ainda presa ao reino europeu; a monarquia nacionalizou-se, os estadistas brasileiros começaram a trabalhar, tendo só em vista os negócios do novo Império (AZEVEDO 1879, p. 5).

Se o elogio ao 7 de Abril mostra a posição particular de Azevedo entre as diferentes vozes dos sócios do Instituto - por vezes, Azevedo usava do elogio ao Império para relembrar dos gestos de despotismo de D. Pedro I -, o que se sucede a este dia é consenso no IHGB: Moreira de Azevedo narrava motins, sedições e revoltas. Assim, além da singularidade conferida ao dia 7 de Abril, essas memórias, embora tratassem de acontecimentos pontuais, compartilhavam um cenário, causas e atores. O tema, as regências, assim como as causas, eram homogêneas. A citação a seguir descreve basicamente as causas principais da anarquia.

Todos esses elementos, os partidos exacerbados, as aspirações ilegais, as paixões violentas, as questões de nacionalidade e a insubordinação militar lançaram em diversos pontos do Império a licença, e produziram comoções, sedições e lutas civis [grifos meus] (AZEVEDO 1871, p. 276).

Cada memória histórica lida com algumas dessas personagens. A imprensa, que "em vez de educar pervertia o povo" (AZEVEDO 1874, p. 180), assim como as "paixões violentas", eram dos poucos elementos recorrentes.

As "questões de nacionalidade" produziam conflitos pelo antagonismo entre o desejo do retorno de D. Pedro I e o repúdio a esse desejo. Nas memórias nas quais essas questões são as personagens centrais, existe uma relação direta entre a dúvida sobre o que é a nação (por sua indefinição no momento) e as lutas civis. "Cada partido, cada facção tratava de exterminar a facção, o partido contrário; era luta de protestantes e católicos, da fogueira e do punhal" (AZEVEDO 1871, p. 277).

A necessidade de definir as linhas gerais da nação não era nada de novo, nem era uma preocupação exclusiva do Instituto em 1870. Certamente, era anterior. O que é necessário destacar é que construir a nação era separá-la da vida dos partidos. Mesmo quando a expectativa do regresso acaba com a morte de D. Pedro I, os partidos mantinham ativas as "aspirações ilegais". A definição desta ilegalidade, porém, não era apenas a lei - que apresentava definições de motim e sedição incorporadas nessas memórias históricas. O que definia a ilegalidade, a licença, era a expansão dos debates políticos para além de certos limites. A voz do passado que se levantou contra a escravidão ao longo das regências, por exemplo, não seria voz. Não seria nem mesmo objeto ou personagem para a escrita da história.

Essa distinção entre voz e ruído não quer dizer que todos os sócios falassem uma mesma coisa, mas que partilhavam de uma mesma tessitura. Nação seria um consenso a ser disputado, e os sócios do Instituto disputaram, porém entre iguais e dentro de certos limites. A disputa política mais intensa, nesse sentido, não é entre a vitória ou a derrota de um projeto, mas sobre os limites do próprio jogo político. 
Nestes, a ação militar seria sempre insubordinação. Fernandes Pinheiro falava também em uma memória histórica, de forma análoga a Moreira de Azevedo: "Ninguém mais do que nós reconhece e admira a sublime dedicação do soldado [...] desejamo-lo, porém, essencialmente passivo, e como o bastão na mão do cego" (PINHEIRO 1874, p. 342).

As regências, enquanto um passado nacional, compunham um repertório pelo qual era possível dar forma e, por ela, representar eventos marcados pelo ruído, pela anarquia. A produção de sentido, o efeito dessa representação, é um controle sobre o ruído, pois que ele permanece num local destacado, ao mesmo tempo em que já fica implícito que todo ruído não só pode como deve ser contido. É uma forma de falar do mundo sem se afetar por ele.

Essa forma de representação acaba tendo consequências sobre a compreensão da vida política, principalmente, na medida em que esta nem sempre é consequência de uma reflexão sistemática. Pelo contrário, se existe um pensamento político brasileiro (FAORO 2007) este está mais na práxis e nas heranças que o Brasil traz consigo do que numa filosofia política (algo que certamente não é exclusivo do Brasil). Aqui, a densidade ou não das heranças é irrelevante, pois que sua força não depende de sua vida interna, mas de sua capacidade de orientar a compreensão. Os partidos exacerbados - por pretenderem se dirigir abertamente à cidade -, a imprensa que inflama - também por se dirigir a um público amplo e por tomar partido - , a turba, a problematização aberta do que é ser brasileiro (o que Azevedo chamava de questões de nacionalidade), eram elementos que orientavam a compreensão da vida política, definiam os limites das disputas.

Há de se ter em vista que a cidade em que o Instituto estava teve sempre uma vida ativa. Especialmente de 1880 em diante, houve um amplo movimento na vida da cidade do Rio de Janeiro que tencionou a paz de que a vida das letras e dos governos pretendia gozar na capital. Essa tensão não era apenas causada pela turba. Para dar apenas um exemplo, um evento como os levantes contra o imposto do vintém de 1880 tiveram como início uma tensão interna na vida do governo entre a câmara municipal da capital, que se opunha ao imposto, e a administração do ministério de Afonso Celso (GRAHAM 2011). A distinção entre voz e ruído não operava apenas sobre as vozes da rua que não deixavam de cismar em falar, mas também no próprio interior da vida do governo. 0 conceito de razão - que neste caso não tem definição própria, mas por seu par antagônico, a paixão - impunha um desejo de "administração depreendida da política", como diria uma voz no Jornal do Comércio em 3 de janeiro de 1878. Ao fim, a compreensão das regências como revolta opera por este antagonismo entre administração e política, onde o político se torna por definição negativo, aberto aos prismas variados, à licença, às aspirações ilegais; não é voz, é ruído. A razão, pelo contrário, era administração autônoma e autocentrada.

Se optamos por discutir essa moldura pontualmente, por meio da escrita da história de Moreira de Azevedo, e não por imersão sincrônica num universo mais amplo de vozes e fontes, isso se deve à aposta em um questionamento sobre como as formas de representação do passado, as molduras que conformam possibilidades de compreensão. 
A força da revolta enquanto moldura aparece na própria reaproximação entre o Instituto Histórico e a vida do governo, quando as regências foram novamente referências intensas para a compreensão da vida política. Nos governos civis, os sócios começavam a falar mais abertamente sobre os recentes governos militares. Eram falas muitas vezes sem nomes, mas com direção clara. Novamente reafirmando a oposição "lá" e "aqui", o então Presidente do IHGB dizia em 1895:

Hoje, corridos vãos os tempos do predomínio da força sobre o direito; da violência sobre a justiça; da guerra, que só destrói e mortifica, sobre a paz que organiza, avigora e consolida os múltiplos elementos que constituem a grandeza e a prosperidade da nação (CASTRO 1895, p. 321).

Aquino e Castro, um ano depois de Prudente de Morais ter comparecido à sessão aniversária do IHGB, seguia opondo a vitória pela ciência à vitória pela força, opondo sua posição e o governo atual ao passado recente da República da Espada. A assimetria "lá" e "aqui" mostrava que ao novo governo de Prudente de Morais os sócios se dedicariam da mesma forma que se dedicaram um dia ao "protetor imediato". Nesse momento, ficavam para trás os anos de dúvida intensa, inclusive sobre a continuidade do IHGB.

Quando a vida do governo se reaproxima do Instituto, os sócios começam a se referir ao passado recente, de 1889 a 1894, da mesma forma que Moreira de Azevedo se referia às regências: "era uma época de transição". A República da Espada se convertia em um momento semelhante às regências, uma "convulsão de uma nação que levantava". A questão "monarquia ou república" se tornava sem sentido. O Império passava a ser incorporado como passado nacional enquanto a República se tornava o presente e o futuro. Esse, porém, não foi o único olhar ou voz sobre a República de 1889. De outro lado estiveram sócios como Tristão Alencar Araripe e Aristides Milton, que justificaram a República como inevitável, como proclamação. O curioso, já adianto, é que esta recepção que de pronto defende a República perde a disputa. Na aproximação entre IHGB e governos civis, triunfa a escolha por retratar 1889 como desencontro, deixando para os governos civis a imagem de início da ordem republicana.

\section{A República como proclamação}

Aqueles que saudaram 1889 percebiam e narravam um passado, dando sentido à República como consequência e conquista da História. Em "Três cidadãos beneméritos da República", por exemplo, Tristão de Alencar afirmava: "O valor patriótico destes três egrégios cidadãos bem pode resumir-se nos seguintes rápidos conceitos: Manoel Deodoro proclamou a República; Benjamin Constant a doutrinou; Floriano Peixoto a consolidou" (ARARIPE 1897, p. 387). Mas até chegar a esse momento, diferentes memórias históricas foram indicando o caminho de ler a República como inevitável.

É o caso de Movimento Colonial na América, memória apresentada pelo mesmo Alencar Araripe em 1890 e que se organiza enquanto narrativa por uma forma específica. Nela, a História ganha movimento por uma lei: a emancipação. 
O caminho, pelo qual a lei é percebida no movimento colonial, não era propriamente uma filosofia da história - embora a escrita pareça subentender uma - mas a exposição de movimentos patrióticos. Não existia uma teoria do progresso propriamente, mas fatos. Assim, em Pernambuco, em 1710, Tupac no Peru de 1780, a "conjuração mineira", a "insurreição das colônias espanholas", todos apareciam como eventos que comprovavam o movimento anunciado: a "emancipação" como "destino fatal". A escolha dos fatos dava um sentido à história, o que não era exclusivo a esta memória.

Desde 1889, a República estava aberta a uma disputa por um novo calendário festivo (OLIVEIRA 1989). Nos limites das páginas da revista do Instituto, Francisco Muniz Tavares e José Domingues Codoceira participavam diretamente do debate que, de uma forma geral, envolvia uma disputa sobre que eventos poderiam expor um desejo inato pela República. Na celebração, era como se os fatos por si garantissem sentido à história. Essa forma específica da celebração parecia, porém, transbordar. Codoceira sintetizava: "Era pela forma republicana que o organismo da nova nacionalidade se manifestava nas convulsões revolucionárias de 1789, 1817, 1822, 1824, 1831, 1835 e 1837" (CODOCEIRA 1890, p. 333). A data celebrada se expandia sobre o passado.

Mesmo no caso de escritas que pareciam romper com esta forma, como é o caso de "A República e a federação no Brasil", de Aristides Milton, ela ainda se mantém. A comparação constante entre as leis da natureza e as leis históricas, que abre o texto, torna-se um meio de, a partir de certos fatos, responder à

222 questão: "Que sucessos nossa História, porventura, denuncia como antecedentes do movimento de que o marechal Deodoro da Fonseca foi feito chefe?" (MILTON 1897, p. 9). Novamente, a resposta remete ao passado colonial dando, nessa memória, forte ênfase no passado recente do Segundo Reinado. O específico da argumentação de Aristides Milton é a demonstração da presença das ideias de República e de Federação no passado nacional.

Essa forma que identifica um instinto pela celebração de uma data que ganha sentido por um conjunto de eventos que seriam como ensaios dela, por sua vez, já era disponível à escrita da história antes da República.

\section{A proclamação como moldura}

As memórias históricas que narravam a primeira proclamação variavam entre narrativas pontuais e outras claramente construídas pelo singular coletivo "a História". Moreira de Azevedo também participou destas escritas. Na memória histórica "O dia 9 de janeiro de 1822", discute duas versões da resposta que D. Pedro I teria dirigido às cortes portuguesas que Ihe exigiam o retorno a Portugal. Assim como outras memórias históricas - parece ser quase uma qualidade de um gênero próprio da escrita da história entre os sócios do Instituto - a narrativa lida com um caso pontual dentro de um cenário amplo. Esse cenário, comum às escritas sobre a Independência, era a intenção das cortes. Nas palavras de Azevedo: "Tratava Portugal da recolonização do Brasil; isto é, a terra de Santa Cruz devia voltar aos tempos de Thomé de Sousa" (AZEVEDO 1868, p. 35). Essa imagem seria repetida, com mais ou menos força, sempre que o tema fosse mobilizado. 
Fernandes Pinheiro, por sua vez, identificava na Revolução Francesa o epicentro de um processo histórico experimentado pela História (PINHERO 1874), operando por um cenário inicial mais amplo. Se em sua forma inicial essa memória se assemelha em muito ao que, anos depois, seria uma história da irresistível Proclamação de 1889, o conteúdo da história contrastava diretamente, assim como a forma que a memória toma em sua maior parte.

O primeiro conteúdo era o "militarismo entre os ibéricos", o que assume um sentido negativo - traço que o cônego via mais acentuado na "raça espanhola". Em segundo, do cenário mais amplo instalado pela Revolução Francesa, a memória se encaminha para uma narrativa que tem um ritmo quase diário, como se fosse uma história política tecida por uma imersão no cotidiano. Desse ritmo, de conversas, textos e decisões narradas dia a dia, o "Prelúdio da Independência" se constrói: "Duas poderosíssimas parcialidades se disputavam a posse do poder: a portuguesa [...]. A outra parcialidade composta dos filhos do país" (PINHEIRO 1868, p. 362). Frente a estas parcialidades, a cooptação do príncipe se tornava fundamental, seja para evitar o caudilhismo que habitava a América espanhola, seja para evitar a anarquia. A questão, porém, ia mais longe. Sem o herdeiro, seriam apenas parcialidades. A aliança com o príncipe era fundamental para que a unidade fosse possível. Sem ele, os prismas variados seriam inevitáveis.

Se esta narrativa de eventos pontuais é comum às memórias históricas sobre as regências, a Independência era menos ruído - embora fosse, por exemplo, no risco dos excessos militares comentados por Fernandes Pinheiro - e mais voz. Assumiam o sentido de voz - inclusive enquanto uma fonte que narra fidedignamente o que se passa - as palavras que se dirigiam ao bem comum e à unidade. Aquela mesma oposição entre razão e paixão entrava em cena, só que agora a razão era personagem justamente quando as parcialidades (ou partidos) eram superadas.

Tristão de Alencar Araripe, com a intenção de discutir a quem cabia o título de patriarca da independência, assumia, por exemplo, a voz do Marques de Sapucaí não só como fonte história, mas também como sentido para a história:

Sabido é já que ninguém pode arrogar-se a gloria, não digo só de ter feito, mas ter apresentado a declaração da emancipação política do Brasil: este ato operou-se tão aceleradamente e por tal unanimidade de votos de todos os Brasileiros que pode dizer-se com verdade que os fatos encaminharam os homens e não os homens os fatos (ARARIPE 1894, p. 169).

A voz do varão distintíssimo colocava a impossibilidade de eleger apenas um patriarca - o que tinha um sentido positivo para Araripe, pois o comando de um homem sobre a nação seria tirania (o exemplo de tirano que o autor dá, nessa mesma memória, é Solano Lopes). Assim como em Moreira de Azevedo ou em Fernandes Pinheiro, a ideia da emancipação ia se formando na consciência dos brasileiros pela força das circunstâncias. A ação das cortes despertava o desejo pela emancipação e mesmo que diferentes personagens fossem constantemente citadas, D. Pedro I tem um papel fundamental. Ele é o 
eixo que garante a unidade, que anula o risco. Também em uma narrativa sobre a primeira proclamação, diria um outro sócio, José Maria Peixoto:

Riam-se os pretensos filósofos, que nós diremos com Pascal: O povo honra as pessoas de grande nascimento [...] Os doutos as consideram não pelo mesmo pensamento que o povo, porém por um mais elevado - a organização social sem dúvida (PEIXOTO 1893, p. 14).

Se existia a necessidade de unidade, ou melhor, de univocidade, existia também a necessidade de passado.

Aconteceu que em caminho de Santos para S. Paulo Sua Alteza recebeu despachos do governo de Portugal e participação do que se passava nas cortes de Lisboa; [...] chamando o príncipe imediatamente a Portugal e anulando as medidas por ele tomadas em bem do país que governava; este fato vinha a ser assim causa ocasional da imediata proclamação da independência, que em verdade se prendia a uma longa série de acontecimentos anteriores; a independência era uma transformação preparada pelo progresso da sociedade, pela força da opinião e pela influência das ideias que se desenvolviam com o andar dos tempos, apresentando aos olhos do observador um resultado previsto e necessário. Enganar-se-ia quem pensasse que era obra do momento (CASTRO 1878, p. 267, grifos meus).

O peso dado à pressão exercida pelas cortes portuguesas podia variar. Na citação acima, extraída de uma biografia escrita por Aquino e Castro 224 (futuro presidente do IHGB na República), por exemplo, era uma "causa ocasional". A moldura também era definida por seu conteúdo, pelo "andar dos tempos".

Vale, assim, sintetizar estas memórias históricas por duas imagens principais já expostas até aqui: 1) "o fato encaminha os homens"; 2) "a independência era uma transformação preparada pelo progresso da sociedade". São imagens complementares. A primeira demonstra o quanto a compreensão do evento político se dava pela busca de destacar referências mais fortes do que as personagens da cena, como se a narrativa buscasse a razão - sempre no singular - que mobilizava as personagens. "Quando não existe domínio das pessoas, prevalece o domínio das ideias, o único eficaz e poderoso para decidir das revoluções ou reformas sociais. Foi o que sucedeu no Brasil de 1822" (ARARIPE 1894, p. 169).

A segunda imagem demonstra o quanto a escolha de quais fatos do passado narrar produz efeitos. Pois a afirmação de que "a independência era uma transformação preparada pelo progresso da sociedade" só era possível pela presença no passado de eventos que se mostrassem como ensaios da Independência. Esta segunda imagem, mais discreta nas memórias históricas sobre a Independência, seria fundamental para narrar a República de 1889 como irresistível. Sendo assim, vale indicar como essas duas imagens, que deram forma a Independência como uma proclamação, foram apropriadas para ver e falar da República de 1889. 
A primeira imagem indica um desafio fundamental para a República. Afinal, não bastava assumir que "os fatos encaminham os homens", era necessário garantir uma "organização social sem dúvida". Como isso se daria em um mundo avesso ao privilégio e ao direito de nascença?

Retomando a memória histórica "Os três beneméritos da República", Alencar Araripe era claro:

[...] o ambiente do Brasil, vivendo nesse meio esplêndido e contemplando espetáculo tão majestoso, não pode receber impressões mesquinhas e deprimentes que toleram o regime do privilégio, onde o acidente fortuito do nascimento estabelece direito para um ente privilegiado governar cidadãos, a quem só a razão e a capacidade devem dirigir (ARARIPE 1897, p. 390, grifos meus).

Na dissolução da ordem garantida pela figura do Imperador, a aposta em um lugar para a razão se tornava ainda mais intensa. E a oposição entre voz e ruído, ainda mais necessária. A oposição entre administração (ou a capacidade) e política (ou os partidos), aliás, permaneceria nas vozes de Deodoro da Fonseca a de Campos Sales. Um dos efeitos da moldura proclamação é essa busca por univocidade e, ao mesmo tempo, por uma associação entre ordem e Estado.

A segunda imagem era igualmente relevante.

Sabemos que os ânimos aferrados a ideias monárquicas inculcam a crença de que a República de 15 de Novembro de 1889 foi um ato de surpresa para o espírito público, e de violência para a maioria da Nação.

Semelhante opinião, porém, só poderia originar-se de falsa apreciação dos fatos da nossa história, ou da ignorância deles, no propósito de desacreditar a causa democrática recentemente triunfante. [...] Basta, porém, ligeiro exame retrospectivo dos acontecimentos da nossa história para reconhecer nessa revolução a consagração formal das aspirações nacionais, sempre reveladas e proclamadas desde os tempos coloniais. Éramos colônias e cedo começamos a lutar pela independência da Pátria e pela República (ARARIPE 1897, p. 399).

A República seria legitimada por "acontecimentos da nossa história", inclusive alguns que antes diziam respeito à Independência. Com exceção de elogios à Revolução de 1817, que antes da República eram quase que exclusividade das falas de Alencar Araripe, alguns fatos eram próximos. Mais do que isso, a escolha de como narrar tinha uma importância tão intensa quanto a escolha de o que narrar.

\section{Considerações finais}

Em 1890, ao se dirigir ao congresso em um discurso em que defendia a necessidade de moderação na (re)formulação da constituição, o presidente da República dizia: "grave é também o perigo das inovações" (FONSECA 1890, p. 7). Deodoro argumentava que a lei era resultado da depuração da história de um povo, não envolvia debates sobre as formas de governo. Um mesmo repertório aparece, o direito fazia parte da "trilogia sagrada" ao lado da justiça e liberdade. Sem ela, era a anarquia. 
A mensagem ao Congresso não acontecia em uma situação ou data qualquer. Deodoro afirmava, em 15 de novembro de 1890, o triunfo da República.

\begin{abstract}
Para vós, que acompanhastes a celebridade e precisão das evoluções republicanas nos últimos anos do império, que fostes também obreiros impulsionadores do movimento que desde os tempos coloniais teve precursores e mártires, não passou de certo indiferente a injustiça com que foi julgada a obra meritória e redentora de 15 de novembro na quase totalidade do velho mundo (FONSECA 1890, p. 5).
\end{abstract}

Ao discutir a legitimidade da República e a forma como esta era lida pelo "velho mundo", Deodoro afirmava a República pelo passado, por seus "precursores e mártires". Esse é o primeiro traço de semelhança entre o repertório em jogo no governo republicano e as escritas da história do IHGB. O argumento é muito próximo ao que Alencar Araripe usaria alguns anos depois em sua escrita dos "Beneméritos da República". Deodoro compartilhava dessa tonalidade comum a alguns sócios do IHGB. Seguia com a "inconfidência mineira" e a "revolução de 1817", assim como Araripe ou Aristides Milton, associando a Independência à República sob o efeito da moldura proclamação.

Ao mesmo tempo, a República se afirmava como uma verdade americana. O "Velho Mundo" não a compreendia, mas na América, dizia Deodoro, a democracia era uma verdade. As escritas do IHGB que elogiavam e defendiam

226 a fala do general. Não se trata, assim, de supor que a vida do governo assumia a escrita da história como referência. O caminho inverso também era possível, não só de argumentos, mas também de posturas. Frente ao que o passado afirma como nação, o homem se curvava.

Se a audiência era composta pelos "obreiros impulsionadores do movimento", Deodoro defendia uma reescrita. O então presidente afirmava que não só as leis eram heranças, como foram graças a elas que a República conquistara estabilidade. Explicitava que fez uso dessas leis em seu governo para controlar a anarquia. As revoltas e motins que a República enfrentava, dizia o General Presidente, eram julgados por um direito, por leis nacionais. 0 direito conformava um vocabulário, inclusive presente nas escritas da história - especialmente sobre as regências - e, ao mesmo tempo, um horizonte. A construção se dava pela herança.

Novamente, assim como nas escritas do IHGB sobre as regências, a vida ativa da rua tinha um nome só, e, novamente, esse nome, anarquia, não era apenas da rua, mas também dos partidos.

No discurso de Deodoro, partido e facção apareciam como elementos distintos; mas que, sem certas precauções, todo partido poderia virar uma facção - assim como fizera Moreira de Azevedo ao falar dos partidos regenciais ou Fernandes Pinheiro se referindo às parcialidades que entravam em cena nos "prelúdios da Independência". O que Deodoro afirmava à sua audiência é que existiam limites. 
Nesta ordem de instituições os partidos políticos constituem a mais eficaz das garantias de estabilidade e de progresso; eles dilatam os domínios da liberdade e defendem a sociedade contra a tirania e as usurpações. Convém, porém, não confundir os partidos com as facções, nem substituir a missão que lhes é própria, humana e prática, pelas abstrações que acaso possam conduzir-nos à revolução ou à dissolução. Demais, sob o regime que adotamos, os partidos ficam sem objetivo no dia em que proferem a sua sentença nas urnas. Desempenhado o seu papel de soberania, todos são indistintamente operários do progresso e da civilização, visto que a aspiração do governo não depende mais nem das impaciências, nem das conspirações (FONSECA 1890, p. 9, grifos meus).

Essa é a definição básica da ação política que Deodoro defendia: o voto. Fora do voto, a ação deveria ser contida. Fora do voto, não se poderia mais se dirigir ao bem de todos, seria como agredir a nação por se movimentar por uma "abstração" ou causa partidária.

Não se está dizendo que não havia partidos na República e que estes não tomaram parte no jogo político. Porém, a cultura política que permeou os governos civis na "política dos governadores" não valorizava a vida dos partidos como uma possibilidade positiva de divergências. A pretensão de uma administração racional anulava justamente a necessidade de disputa. Campos Sales quando presidente dizia, de forma ainda mais enfática que Deodoro:

Aquele que é elevado pela vitória das urnas à suprema direção dos destinos do País não é, de certo, o chefe de um partido, representante de suas paixões e animado do ódio contra os vencidos; mas representa antes de tudo e acima de tudo um triunfo de princípios e ideias, uma sanção pedida à maioria da nação e outorgada por ela. Ele é, pois, o chefe legítimo do Estado (apud LESSA 1988, p. 90).

Existia uma autonomia do eleito pela "maioria da nação" em relação ao seu partido. Por sua vez, se para Deodoro o voto era a definição básica da ação política do cidadão, o voto permaneceria nos governos civis com esse mesmo sentido, e os partidos, de igual forma, ficavam sem função após as eleições. Ir além disso era correr o risco de se tornar uma facção.

O que se está destacando é que não é sem razão que os sócios do IHGB, por exemplo, iriam associar Canudos às revoltas regenciais: o horizonte ainda se mantinha. Na primeira década da República, apesar da diversidade dos jogos políticos (FREIRE 2006), mesmo que as intenções fossem por vezes contrastantes e distintas entre si, mesmo que estivessem em disputa diferentes projetos para a República, o que entrava em jogo também eram heranças.

Ao fim, a proclamação, enquanto moldura, parece ter sido mais ativa sobre aquilo que se queria ver como passado legítimo. Um evento fundamental, mas sobretudo acabado. Algo que não precisa ser revisto, muito menos revivido, a não ser enquanto celebração. A revolta, porém, aparentemente menos forte ou de menor presença, teria uma amplitude muito maior, compondo uma unidade na qual a vida da cidade ou dos partidos não era nada mais do que ruído.

As semelhanças ente escrita da história e vocabulário político não são fortuitas. Não implica dizer que o passado as defina, nem que a história tenha 
um peso fundamental sobre a vida política. O caso talvez seja justamente de reconhecer que é um movimento de mão dupla, o que traz a pergunta: mas que vida política anima e perpassa nossas escritas da história?

\section{Referências bibliográficas}

ARARIPE, Tristão de Alencar. Movimento colonial na América. Revista do IHGB, t. 56, p. 91-115, 1893.

- Patriarcas da Independência. Revista do IHGB, t. 57, p. 167-184, 1894.

. Três cidadãos beneméritos da República. Revista do IHGB, t. 60, p. 385-396, 1897.

AZEVEDO, Manuel Duarte Moreira de. Declaração da maioridade do Imperador em 1870. Revista do IHGB, t. 42, p. 5-37, 1879.

- Motim político de 17 de Abril de 1832 no Rio de Janeiro. Revista do IHGB, t. 38, p. 127-141, 1875.

. Os tiros no teatro: motim popular no Rio de Janeiro. Revista do IHGB,

t. 36 , p. $349-358,1873$.

. Sedição militar na Ilha das Cobras em 1831. Revista do IHGB, t. 34, p. 276-292, 1871.

228 . Sedição militar de julho de 1831 no Rio de Janeiro. Revista do IHGB, t. 37 , p. $179-190,1874$.

BLAKE, Augusto Vitorino A. Sacramento. Parecer sobre Vultos e fatos. Revista do IHGB, t. 55, p. 375, 1892.

CASTRO, Olegário Herculano de Aquino e. Discurso do Presidente do Instituto: Sessão magna aniversária. Revista do IHGB, t. 58, p. 321, 1895. - Biografia do Conselheiro Manoel Joaquim do Amaral Gurgel. Revista do IHGB, t. 41, p. 237-376, 1878.

CARVALHO, José Murilo. A formação das almas: o imaginário da República no Brasil. São Paulo: Companhia das Letras, 1990.

CEZAR, Temístocles. A retórica da nacionalidade de Varnhagen e o mundo antigo: o caso da origem dos tupis. In: GUIMARÃES, Manoel Salgado. Estudos sobre a escrita da história. Rio de Janeiro: 7Letras, 2006, p. 29-41.

CODOCEIRA, José Domingues. Exposição de fatos históricos que comprovam a prioridade de Pernambuco na independência e liberdade nacional. Revista do IHGB, t. 53, p. 327-342, 1890.

CORREIA, Manuel Francisco. Discurso do Vice-Presidente. Revista do IHGB, t. 60, 1897.

FAORO, Raymundo. A República inacabada. São Paulo: Globo, 2007. 
FONSECA, Deodoro. Mensagem dirigida ao congresso. Rio de Janeiro, 15 de novembro de 1890. Disponível em: www.crl.edu/brazil/presidential.

FREIRE, Américo. Ensaio sobre o governo da (Primeira) República Brasileira. In: MARTINHO, Francisco Carlos Palomanes (org.). Democracia e ditadura no Brasil. Rio de Janeiro: Ed. Uerj, 2006, p. 39-49.

GRAHAM, Sandra. O motim do Vintém e a cultura política do Rio de Janeiro, 1880. In: DANTAS, Mônica Duarte (org.). Revoltas, Motins, Revoluções. São Paulo: Alameda, 2011, p. 485-506.

GUIMARÃES, Lucia Maria Pascoal. Debaixo da imediata proteção de Sua Majestade Imperial. Revista do IHGB, v. 156, n. 388, 1995.

Da Escola Palatina ao Silogeu: Instituto Histórico e Geográfico Brasileiro (1889-1938). Rio de Janeiro: Museu da República, 2007.

GOMES, Ângela de Castro. A República, a História e o IHGB. Belo Horizonte: Argvmentvm, 2009.

GUMBRECHT, Hans Ulrich. As funções da retórica parlamentar na Revolução Francesa. Belo Horizonte: Editora da UFMG, 2003.

HRUBY, Hugo. Obreiros diligentes e zelosos auxiliando no preparo da grande obra: a História do Brasil no Instituto Histórico e Geográfico Brasileiro (1889-1912). Dissertação (Mestrado em História). Programa de Pós-Graduação em História, Pontifícia Universidade Católica do Rio Grande do Sul, Porto Alegre, 2007.

LESSA, Renato. A invenção Republicana. São Paulo: Editora Vértice; Rio de Janeiro: Iuperj, 1988.

MELLO, José Alexandre Teixeira de. Relatório. Revista do IHGB, t. 53, p. 561, 1890.

MELlo, Maria Tereza Chaves de. A República Consentida. Rio de Janeiro: Editora da FGV; Editora da Universidade Federal Rural do Rio de Janeiro, 2007.

MILTON, Aristides Augusto. A República e a federação no Brasil. Revista do IHGB, t. 60, p. 5-33, 1897.

. A campanha de Canudos. Revista do IHGB, t. 63, p. 5-147, 1900.

OLIVEIRA, Lúcia Lippi. As Festas que a República Manda Guardar. Estudos Históricos, Rio de Janeiro, v. 2, n. 4, p. 172-189, 1989.

A questão nacional na Primeira República. São Paulo: Brasiliense, 1990.

PINHEIRO, Joaquim Caetano Fernandes. Motins políticos e militares no Rio de Janeiro: prelúdios da Independência do Brasil. Revista do IHGB, t. 37, p. 341-366, 1874.

PEIXOTO, José Maria Pinto. Duas palavras sobre D. Pedro I na época da Independência. Revista do IHGB, t. 56, p. 5-33, 1893. 
SILVA, Joaquim Norberto de Souza e. Discurso. Revista do IHGB, t. 52, p. 534, 1889.

SILVEIRA, Argemiro. Alguns apontamentos biográficos de Libero Badaró. Revista do IHGB, t. 53, p. 309-384, 1890.

SIMAS, Luiz Antônio. 0 evangelho segundo os Jacobinos: Floriano Peixoto e o mito do salvador da república brasileira. Dissertação (Mestrado em História). Programa de Pós-Graduação em História, Universidade Federal do Rio de Janeiro, Rio de Janeiro, 1994. 